\title{
Growth Inhibitory Activity of Indian Terminalia spp. against the Zoonotic Bacterium Bacillus anthracis
}

\author{
Mitchell Henry Wright, ${ }^{1}$ Reece Courtney, ${ }^{1,2}$ Anthony Carlson Greene, ${ }^{1}$ lan Edwin Cock, ${ }^{1,2^{*}}$ \\ 'School of Natural Sciences, Nathan Campus, Griffith University, 170 Kessels Rd, Nathan, Queensland 4111, AUSTRALIA. \\ ¿Environmental Futures Research Institute, Nathan Campus, Griffith University, 170 Kessels Rd, Nathan, Queensland 4111, AUSTRALIA.
}

\begin{abstract}
Introduction: Anthrax is a zoonotic disease caused by the soil bacterium Bacillus anthracis. It has an extremely high mortality rate if untreated. Terminalia spp. have a long association with the treatment of various ailments, including bacterial infections although they have not been tested for the ability to inhibit the growth of B. anthracis. Methods: Solvent extracts were prepared using Terminalia spp. known to inhibit microorganism growth. The antibacterial potential of the extracts were investigated by disc diffusion assay to determine the growth inhibitory potential against an environmental strain of $B$. anthracis. Their MIC values were calculated to quantify and compare their relative efficacies. Toxicity was determined using the Artemia franciscana nauplii bioassay. Results: Extracts prepared from several Indian Terminalia spp. displayed potent antibacterial activity in the disc diffusion assay against $B$. anthracis. The methanolic T. chebula fruit extract was particularly effective at inhibiting microbial growth, with MIC values against $B$. anthracis of $166 \mu \mathrm{g} / \mathrm{mL}(<2 \mu \mathrm{g}$ impregnated in the disc). The aqueous $T$. chebula extract, as well as T. catappa and T. arjuna methanolic extracts, were also good growth inhibitors with MIC's generally $<2500 \mu \mathrm{g} / \mathrm{mL}(<25 \mu \mathrm{g}$ impregnated in the disc). All other plant extracts
\end{abstract}

were either inactive or of only low inhibitory activity. None of the extracts were deemed toxic, with all recorded $L_{50}$ values substantially $>1000 \mu \mathrm{g} / \mathrm{mL}$. Conclusion: The potent growth inhibitory activity of the methanolic $T$. chebula fruit extract against $B$. anthracis indicates its potential in the treatment and prevention of anthrax. Furthermore, due to its low toxicity, its use may extend to all forms of the disease (cutaneous, inhalation or gastrointestinal) and may extend to live stock as well as humans.

Key words: Terminalia, Antibacterial activity, Terminalia chebula, Terminalia catappa, Terminalia arjuna, Anthrax, Traditional medicine.

\section{Correspondence:}

Ian Edwin Cock, School of Natural Sciences, Nathan Campus, Griffith University, 170 Kessels Rd, Nathan, Queensland 4111, AUSTRALIA. Phone no: +61 7 37357637; Fax no: +61 737355282

E-mail: I.Cock@griffith.edu.au

DOI : $10.5530 /$ pc.2016.1.2

\section{INTRODUCTION}

Bacillus anthracis is a sporulating gram-positive bacterium and the causative agent of the zoonotic disease anthrax. Present ubiquitously in soils worldwide, $B$. anthracis is dissimilar to other organisms within the $B a$ cillus genus in that it produces the lethal anthrax toxin. While linked to several bioterrorism attacks and highly fatal to humans, the bacterium predominately affects feeding ruminants through the inhalation of endospores. ${ }^{1}$ Under environmental stresses such as nutrient deprivation, vegetative cells divide to metabolically inactive spores that can remain dormant for prolonged periods of time., ${ }^{2,3}$ Once these are internalised, the spores revert and subsequently produce the anthrax toxin which ultimately leads to death. After a period of time, spore production once again proceeds and improper handling of the infected carcases can result in the zoonotic transfer to people. Indeed, the primary mode of human infection is through the ingestion, inhalation or direct contact of spores to skin abrasions originating from contaminated animal sources. ${ }^{4} \mathrm{Human}$ infection of anthrax can be divided into three forms: cutaneous (contact of spores to skin lesions), gastrointestinal (ingestion) and pulmonary (inhalation of spores). Cutaneous anthrax, the most common form of the disease, is characterised primarily through the formation of visible black eschars. ${ }^{5}$ Although the most prevalent, it is also the most easily treated and if discovered early is rarely fatal. ${ }^{6}$ Gastrointestinal anthrax is caused through the consumption of contaminated meat and occurrence is rare in developed nations and more frequent in countries without stringent quality control programs. Symptoms include vomiting of blood, severe diarrhoea and lesions from the oral cavity to the cecum. ${ }^{7}$ Pulmonary anthrax is the most deadly form of the disease and is historically associated with bioterrorism, although infection can also occur through industrial contact (wool mills, tanneries etc). Symptoms include respiratory failure, multi-organ failure and shock, and if left untreated have up to a $90 \%$ mortality rate. ${ }^{8}$
Current antibiotic strategies include the combination of both intravenous and oral antibiotics, including ciprofloxacin, doxycycline and penicillin G. ${ }^{9}$ While considered the most effective method of treatment, there is always an inherent risk that the bacterium may develop an antibiotic resistance to one or more of this antibiotics.Indeed, strains with naturally conferred resistances to penicillins and cephalosporins have been previously isolated. ${ }^{10}$ Furthermore, a tailored, multi-drug resistant strain of B.anthracis may be used in bioterrorism which would decrease available treatment options. Therefore the synthesis of new drugs or discovery of antibacterial compounds in pre-existing natural assets is vital to ensure viable treatment options are available.The antimicrobial properties of medicinal plants have long been recognised by many cultures and the identification of the active compounds offers potential in the development of new anti- $B$. anthracis agents. Thus the investigation of natural assets provides an opportunity to discover compounds effective in the treatment of anthrax.

The genus Terminalia encompasses approximately 200-250 species of flowering trees and has an extensive association with usage in traditional medicinal systems. ${ }^{11}$ The antibacterial activity of this genus has been extensively reported. Extracts prepared from the fruit of the Australian species Terminalia ferdinandiana (Kakadu plum) have potent growth inhibitory activity against an extensive panel of pathogenic bacteria including bacteria associated diarrhoea and dysentery ${ }^{12}$ as well as the bacterial triggers of rheumatoid arthritis (Proteus mirabilis) ${ }^{13}$ and multiple sclerosis (Acinitobacterbaylyi and Pseudomonas aeruginosa). ${ }^{14}$ Leaf extracts from the same species have also been shown to inhibit growth of the same bacteria, as well as a microbial trigger of ankylosing spondylitis (Klebsiella pneumoniae). ${ }^{15}$ Similarly, African Terminalia spp. are potent bacterial growth inhibitors. Terminalia stenostachya and Terminalia spinosahave strong antibacterial activity against a broad spec- 
trum of medicinally important bacteria including several Mycobacterium spp., Streptococcus faecalis, Staphylococcus aureus, Vibrio cholera, Bacillus anthracis, Klebsiella pneumoniae, Salmonella typhi, Pseudomonas aeruginosa and Escherichia coli. ${ }^{16}$ Recent studies have demonstrated the growth inhibitory activity of Terminalia sericea and Terminalia pruinoides against pathogenic ${ }^{17}$ and food spoilage bacteria. ${ }^{18}$ Many Indian Terminalia spp. have a history of therapeutic uses, many of which are related to microbial infections (Table 1). Numerous recent investigations have reported on their antibacterial properties. Leaf and branch extracts of Terminalia arjuna, have antibacterial activity against a wide panel of microbes. ${ }^{19,20}$ Terminalia chebula has traditional uses in Ayurveda for the treatment of numerous diseases and conditions ${ }^{21}$ and has potent antibacterial activity. ${ }^{19}$ Similarly, Terminalia alata, Terminalia bellirica and Terminalia catappa have broad spectrum antibacterial activity. ${ }^{20}$ However, despite the wealth of antibacterial studies for Terminalia spp., there is a lack of studies screening Terminalia spp. for the ability to inhibit B. anthracis growth. Indeed, a literature search only found a single study which reported B. anthracis growth inhibitory activity for T. stenostachya and T. spinos $a^{16}$ and a further study which reported lack of inhibitory activity for Terminalia glaucescens. ${ }^{22}$ Our study was undertaken to examine the ability of selected Asian Terminalia spp. with extensive usage in Ayurvedic medicine for the ability to inhibit B. anthracis growth.

\section{MATERIALS AND METHODS}

\section{Plant source and extraction}

The Terminalia chebula, Terminalia catappa and Terminalia arjuna plant materials used in this study were a gift from Dr Paran Rayan, Griffith University. Voucher samples of all plant specimens have been stored at the School of Natural Sciences, Griffith University, Brisbane Australia. The plant materials were thoroughly desiccated in a Sunbeam food dehydrator and the dried materials stored at $-30^{\circ} \mathrm{C}$ until use. Prior to usage, the materials were thawed and ground into a coarse powder. Individual $1 \mathrm{~g}$ quantities of the material were weighed into separate tubes and $50 \mathrm{~mL}$ of methanol, deionised water, chloroform, hexane or ethyl acetate were added. All solvents were obtained from Ajax and were AR grade. The ground plant materials were individually extracted in each solvent for 24 hours at $4^{\circ} \mathrm{C}$ with gentle shaking. The extracts were then filtered through filter paper (Whatman No. 54) under vacuum, followed by drying by rotary evaporation in an Eppendorf concentrator 5301 .
The resultant extracts were weighed and redissolved in $10 \mathrm{~mL}$ deionised water (containing 1\% DMSO).

\section{Qualitative phytochemical studies}

Phytochemical analysis of the extracts for the presence of tannins, saponins, triterpenoids, phenolic compounds, flavonoids, phytosteroids, cardiac glycosides, anthraquinones, and alkaloids was conducted as previously described. ${ }^{28-30}$

\section{Antibacterial screening \\ Environmental Bacillus anthracis strain}

An environmental strain of Bacillus anthracis was isolated and used in these studies. The bacterium was originally isolated from a water sample taken from Paralana hot springs ( $30^{\circ} 17^{\prime} 49^{\prime \prime}$ S, $\left.139^{\circ} 44^{\prime} 15^{\prime \prime} \mathrm{E}\right)$, South Australia. Isolation was achieved through successive culturing steps using a modified peptone/yeast extract (PYE) agar as previously described. ${ }^{31}$ The GenBank accession number for the 16S rRNA gene sequence for the isolate is KR003287.

\section{Evaluation of antimicrobial activity}

The antimicrobial activity of all plant extracts was assessed using a modified disc diffusion assay as previously described. ${ }^{32-34}$ Briefly, $100 \mu \mathrm{L}$ of $B$. anthracis was grown in $10 \mathrm{~mL}$ of fresh PYE media until a cell count of approximately $10^{8}$ cells $/ \mathrm{mL}$ was achieved. An amount of $100 \mu \mathrm{L}$ of bacterial suspension was spread onto nutrient agar plates. The extracts were tested for antibacterial activity using $5 \mathrm{~mm}$ sterilised filter paper discs. Discs were infused with $10 \mu \mathrm{L}$ of the text sample, allowed to dry and placed onto inoculated plates. The plates were allowed to stand at $4^{\circ} \mathrm{C}$ for 2 hours before incubation at $30^{\circ} \mathrm{C}$ for 24 hours. The diameters of the inhibition zones were measured in millimetres. All measurements were rounded to the closest whole millimetre. Each assay was performed in at least triplicate. Mean values $( \pm$ SEM) are reported in this study. Standard discs of chloramphenicol $(10 \mu \mathrm{g})$ and penicillin-G $(2 \mu \mathrm{g})$ were obtained from Oxoid Ltd. and served as positive controls for antibacterial activity. Filter discs infused with $10 \mu \mathrm{L}$ of sterilised water were used as a negative control.

\section{Minimum inhibitory concentration (MIC) determination}

The minimum inhibitory concentration (MIC) of each extract was determined as previously described. ${ }^{35,36}$ Briefly, the plant extracts were diluted

Table 1: The medicinal usage, common names and known constituents of the Indian Terminalia species tested in this study

\begin{tabular}{|c|c|c|c|c|c|}
\hline Plant Species & $\begin{array}{l}\text { Part Used in This } \\
\text { Study }\end{array}$ & Common Name/s & Traditional Medicinal Uses & Known Constituents & References \\
\hline $\begin{array}{l}\text { Terminalia } \\
\text { chebula }\end{array}$ & fruit & $\begin{array}{l}\text { Chebulic Myroblan, Black } \\
\text { Myroblan, Haritaki, Inknut }\end{array}$ & $\begin{array}{l}\text { Used externally to treat fungal } \\
\text { infections and cutaneous wounds and } \\
\text { in the prevention of inflammation } \\
\text { of the mucosal membrane of the } \\
\text { mouth. Used internally as a laxative } \\
\text { and is known for its purgative effects. } \\
\text { Known to have uses in the treatment } \\
\text { of asthma and coughs. }\end{array}$ & $\begin{array}{c}\text { Terflavin B and chebulinic } \\
\text { acid }\end{array}$ & 11,23 \\
\hline $\begin{array}{l}\text { Terminalia } \\
\text { catappa }\end{array}$ & fruit & $\begin{array}{l}\text { Indian almond, tropical } \\
\text { almond, umbrella tree }\end{array}$ & $\begin{array}{l}\text { Therapeutic effects for liver related } \\
\text { diseases, anticancer activity as well } \\
\text { as effective in the blocking of HIV } \\
\text { reverse transcriptase. Additionally } \\
\text { known to have antidiabetic benefits. }\end{array}$ & $\begin{array}{l}\text { Flavonoids (including } \\
\text { kaempferol, quercetin), } \\
\text { tannins, saponins } \\
\text { andphytosterols }\end{array}$ & $11,24,25$ \\
\hline $\begin{array}{l}\text { Terminalia } \\
\text { arjuna }\end{array}$ & branch & $\begin{array}{c}\text { Arjuna, Koha, White } \\
\text { Marudah }\end{array}$ & $\begin{array}{l}\text { Treatment of cardiovascular disorders } \\
\text { as well as anti-inflammatory } \\
\text { properties. Known to aid in the } \\
\text { elimination of cholesterol. Also an } \\
\text { analgesic and an antioxidant. }\end{array}$ & $\begin{array}{l}\text { Triterpenoids, } \\
\text { flavonoids, tannins, } \\
\text { gallic and ellagic acid, } \\
\text { sitosterol,proanthocyanidins }\end{array}$ & $11,26,27$ \\
\hline
\end{tabular}


in deionised water and tested across a range of concentrations. Discs were infused with $10 \mu \mathrm{L}$ of the test dilutions, allowed to dry and placed onto inoculated plates. The assay was achieved as outlined above and graphs of the zone of inhibition versus concentration were plotted for each extract. Linear regression was used to calculate the MIC values of each extract.

\section{Toxicity screening}

\section{Reference toxin for toxicity screening}

Potassium dichromate $\left(\mathrm{K}_{2} \mathrm{Cr}_{2} \mathrm{O}_{7}\right)$ (AR grade, Chem-Supply, Australia) was prepared as a $4 \mathrm{mg} / \mathrm{mLsolution}$ in distilled water and was serially diluted in artificial seawater for use in the Artemia franciscana nauplii bioassay.

\section{Artemia franciscana nauplii toxicity screening}

Toxicity was tested using an adapted Artemia franciscana nauplii lethality assay as previously described. ${ }^{37-39}$ Briefly, $400 \mu \mathrm{L}$ of seawater containing approximately 43 (mean 43.2, $\mathrm{n}=155, \mathrm{SD} 14.5$ ) A. franciscana nauplii were added to wells of a 48 well plate and immediately used for bioassay. A volume of $400 \mu \mathrm{L}$ of diluted plant extracts or the reference toxin were transferred to the wells and incubated at $25 \pm 1^{\circ} \mathrm{C}$ under artificial light (1000 Lux). A negative control $(400 \mu \mathrm{L}$ seawater) was run in triplicate for each plate. All treatments were performed in at least triplicate. The wells were checked at regular intervals and the number of dead counted. The nauplii were considered dead if no movement of the appendages was detected within 10 seconds. Following 24 h exposure, all nauplii were sacrificed and counted to determine the total \% mortality per well. The $\mathrm{LC}_{50}$ with $95 \%$ confidence limits for each treatment was determined using probit analysis.

\section{Statistical analysis}

Data are expressed as the mean \pm SEM of at least three independent experiments.

\section{RESULTS}

\section{Liquid extraction yields and qualitative phytochemical screening}

Extraction of $1 \mathrm{~g}$ of the various dried plant materials with the solvents yielded dried plant extracts ranging from $22 \mathrm{mg}$ (T. arjuna leaf ethyl acetate extract) to $634 \mathrm{mg}$ (T. chebula methanolic fruit extract) (Table 2). In general, $T$. chebula fruit extracts gave higher yields of dried extracted material compared with the corresponding extracts of the other Terminalia spp. The exceptions were the low polarity (chloroform and hexane) T. catappa fruit extracts, both of which had substantially higher amounts of extracted material than the corresponding T. chebula and T. arjuna extracts. Indeed, the T. catappa chloroform and hexane extracts had greater masses of extracted material than the aqueous and methanolic extracts. The dried extracts were resuspended in $10 \mathrm{~mL}$ of deionised water (containing 1\% DMSO) resulting in the extract concentrations shown in Table 2.

Qualitative phytochemical studies showed that the methanolic and aqueous extracts of all species generally had a wide range of phytochemicals (Table 2). Both solvents generally extracted high levels of phenolics (particularly water soluble phenolics) for all plant materials. The methanolic and aqueous extracts generally extracted high levels of flavonoids and tannins and moderate to high levels of saponins. The ethyl acetate extracts had similar phytochemical profiles as the methanolic and aqueous extracts, although most classes of compounds were present at lower abundance. In contrast, the chloroform and hexane extracts of most of the Terminalia plant specimens generally only had low to moderate levels of phenolics, flavonoids and tannins. The chloroform and hexane extracts were generally devoid of detectable levels of the other classes of phytochemicals.

Table 2: The mass of dried extracted material, the concentration after resuspension in deionised water and qualitative phytochemical screenings of the plant extracts

\begin{tabular}{|c|c|c|c|c|c|c|c|c|c|c|c|c|c|c|c|c|c|}
\hline $\begin{array}{l}\frac{y}{u} \\
\mathscr{y} \\
\text { v }\end{array}$ & 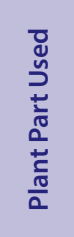 & & 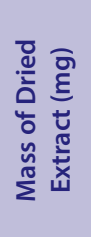 & 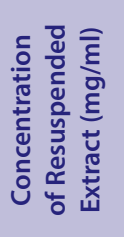 & 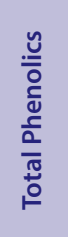 & 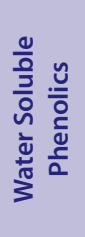 & 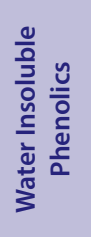 & 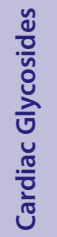 & 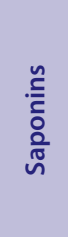 & 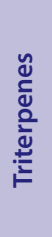 & 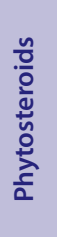 & 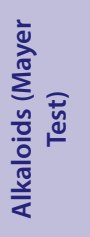 & 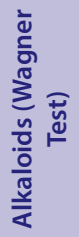 & \begin{tabular}{l}
$\frac{n}{0}$ \\
\hdashline 0 \\
$\frac{0}{0}$ \\
$\frac{\pi}{4}$
\end{tabular} & 站 & 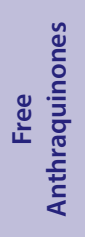 & 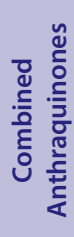 \\
\hline T. chebula & fruit & $\mathrm{W}$ & 438 & 43.8 & +++ & +++ & +++ & - & +++ & - & - & - & - & +++ & +++ & ++ & - \\
\hline T. chebula & fruit & M & 634 & 63.4 & +++ & +++ & +++ & - & +++ & - & - & - & - & +++ & +++ & ++ & - \\
\hline T. chebula & fruit & $\mathrm{C}$ & 93 & 9.3 & + & - & - & - & - & - & - & - & - & - & + & - & - \\
\hline T. chebula & fruit & $\mathrm{H}$ & 104 & 10.4 & - & - & - & - & - & - & - & - & - & - & - & ++ & - \\
\hline T. chebula & fruit & $\mathrm{E}$ & 62 & 6.2 & +++ & ++ & + & - & - & - & - & - & - & +++ & +++ & - & - \\
\hline T. catappa & fruit & $\mathrm{W}$ & 144 & 14.4 & +++ & +++ & ++ & + & ++ & - & - & ++ & ++ & ++ & +++ & - & - \\
\hline T. catappa & fruit & M & 231 & 23.1 & +++ & +++ & ++ & + & - & - & - & + & ++ & ++ & +++ & - & - \\
\hline T. catappa & fruit & $\mathrm{C}$ & 434 & 43.4 & + & + & - & + & - & - & - & - & - & + & + & - & - \\
\hline T. catappa & fruit & $\mathrm{H}$ & 447 & 44.7 & + & + & - & - & - & - & - & - & - & - & + & - & - \\
\hline T. catappa & fruit & $\mathrm{E}$ & 353 & 35.3 & + & + & - & - & - & - & - & - & + & + & + & - & - \\
\hline T. arjuna & leaf & $\mathrm{W}$ & 144 & 14.4 & +++ & +++ & +++ & - & ++ & - & - & - & - & +++ & +++ & + & - \\
\hline T. arjuna & leaf & M & 40 & 4.0 & +++ & +++ & +++ & - & +++ & - & - & - & - & +++ & +++ & + & - \\
\hline T. arjuna & leaf & $\mathrm{C}$ & 92 & 9.2 & + & + & - & - & - & - & - & - & - & - & + & - & - \\
\hline T. arjuna & leaf & $\mathrm{H}$ & 136 & 13.6 & - & - & - & - & - & - & - & - & - & - & - & - & - \\
\hline T. arjuna & leaf & $\mathrm{E}$ & 22 & 2.2 & + & - & - & - & - & - & - & - & - & + & + & - & - \\
\hline
\end{tabular}

+++ indicates a large response; ++ indicates a moderate response; + indicates a minor response; - indicates no response in the assay. $\mathrm{W}=$ aqueous extract; $\mathrm{M}=$ methanolic extract; $\mathrm{C}=$ chloroform extract; $\mathrm{H}=$ hexane extract; $\mathrm{E}=$ ethyl acetate extract. 


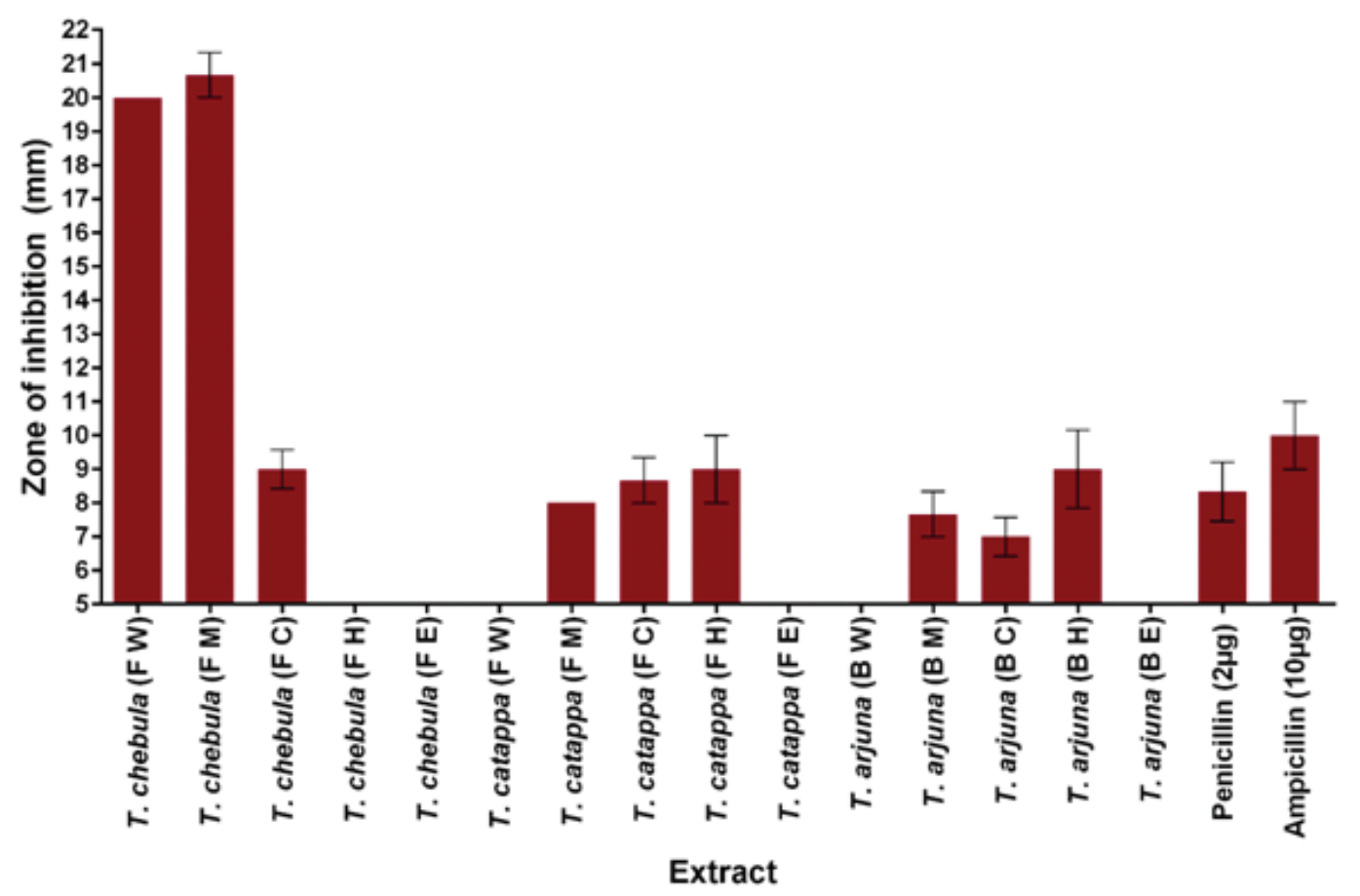

Figure 1: Growth inhibitory activity ofplant extracts against the $B$. anthracis environmental isolate measured as zones of inhibition $(\mathrm{mm}) . \mathrm{F}=$ fruit; $\mathrm{B}=$ branch; $\mathrm{W}=$ aqueous extract; $\mathrm{M}=$ methanolic extract; $\mathrm{C}=$ chloroform extract; $\mathrm{H}=$ hexane extract; $\mathrm{E}=$ ethyl acetate extract. Results are expressed as mean zones of inhibition $\pm \mathrm{SEM}$.

\begin{tabular}{|c|c|c|c|c|}
\hline Species & Part & Extract & MIC $(\mu \mathrm{g} / \mathrm{mL})$ & $\mathrm{LC}_{50}(\mu \mathrm{g} / \mathrm{mL})$ \\
\hline T. chebula & fruit & W & 1975 & 2246 \\
\hline T. chebula & fruit & M & 166 & 1883 \\
\hline T. chebula & fruit & $\mathrm{C}$ & 9400 & - \\
\hline T. chebula & fruit & $\mathrm{H}$ & - & - \\
\hline T. chebula & fruit & E & - & - \\
\hline T. catappa & fruit & W & - & 1873 \\
\hline T. catappa & fruit & M & 2640 & 1452 \\
\hline T. catappa & fruit & $\mathrm{C}$ & $>10000$ & - \\
\hline T. catappa & fruit & $\mathrm{H}$ & $>10000$ & - \\
\hline T. catappa & fruit & E & - & - \\
\hline T. arjuna & branch & W & - & 2094 \\
\hline T. arjuna & branch & M & 1608 & 1683 \\
\hline T. arjuna & branch & $\mathrm{C}$ & 9200 & - \\
\hline T. arjuna & branch & $\mathrm{H}$ & $>10000$ & - \\
\hline T. arjuna & branch & E & - & - \\
\hline
\end{tabular}

Numbers indicate the mean MIC and $\mathrm{LC}_{50}$ values of triplicate determinations. - indicates no bacterial growth inhibition was evident, or that an $\mathrm{LC}_{50}$ value could not be obtained as the mortality did not reach $50 \%$ for any dose tested. $\mathrm{W}=$ aqueous extract; $\mathrm{M}=$ methanolic extract; $\mathrm{C}=$ chloroform extract; $\mathrm{H}=$ hexane extract; $\mathrm{E}=$ ethyl acetate extract. 


\section{Antimicrobial activity}

To determine the ability of the crude plant extracts to inhibit the growth of $B$. antharcis, aliquots $(10 \mu \mathrm{L})$ of each extract were screened using a disc diffusion assay. The bacterial growth was inhibited by 9 of the 15 extracts screened (60\%) (Figure 1). The T. Chebula aqueous and methanolic fruit extracts were the most potent inhibitor of $B$. antharcis growth (as judged by zone of inhibition), with inhibition zones of $20.7 \pm 0.7 \mathrm{~mm}$ and $20.0 \pm 0 \mathrm{~mm}$ respectively.This compares favourably with the penicillin and ampicillin controls, which had zones of inhibition of $8.3 \pm 0.6$ and $9.6 \pm 0.6 \mathrm{~mm}$ respectively. The T. chebula chloroform extracts also displayed good growth inhibitory activity $(9.3 \pm 0.3 \mathrm{~mm})$, whilst the T. chebula hexane and ethyl acetate extracts were devoid of growth inhibitory activity. The T. catappa methanolic, chloroform and hexane extracts, as well as the T. arjuna methanolic, chloroform and hexane extracts also displayed moderate inhibitory activity. All other extracts were devoid of $B$. antharcis growth inhibitory activity.

The antimicrobial efficacy was further quantified by determining the MIC values (Table 3). The methanolic T. chebula fruit extract was particularly effective at inhibiting microbial growth, with MIC values against $B$. anthracis of $166 \mu \mathrm{g} / \mathrm{mL}(<2 \mu \mathrm{g}$ impregnated in the disc). The aqueous T. chebula fruit extract, as well as the T. catappa and T. arjuna methanolic extracts were also displayed good growth inhibition with MIC's generally $<2500 \mu \mathrm{g} / \mathrm{mL}$ ( $<25 \mu \mathrm{g}$ impregnated in the disc). All other plant extracts were either inactive or of only low inhibitory activity.

\section{Quantification of toxicity}

All extracts were initially screened at $2000 \mu \mathrm{g} / \mathrm{mL}$ in the assay (Figure 2). For comparison, the reference toxin potassium dichromate $(1000 \mu \mathrm{g} / \mathrm{mL})$ was also tested in the bioassay. The potassium dichromate reference tox- in was rapid in its onset of mortality, inducing nauplii death within the first 3 hours of exposure and 100\% mortality was evident following 4-5 hours (results not shown). The aqueous and methanolic extracts of all Terminalia spp. were toxic in the Artemia nauplii bioassay, with> 50\% mortality rates at $24 \mathrm{~h}$. The mortality for all other extracts was not significantly different to the mortality seen for the seawater control.

To further quantify the effect of toxin concentration on the induction of mortality, the extracts were serially diluted in artificial seawater to test across a range of concentrations in the Artemia nauplii bioassay. Table 3 shows the $\mathrm{LC}_{50}$ values of the extracts towards $A$. franciscana. No LC $_{50}$ values are reported for the chloroform, hexane and ethyl acetate extracts of any Terminalia spp. as $<50 \%$ mortality was seen for all concentrations tested. All other extracts were determined to be nontoxic, with $\mathrm{LC}_{50}$ values substantially greater than $1000 \mu \mathrm{g} / \mathrm{mL}$ following $24 \mathrm{~h}$ exposure. Extracts with an $\mathrm{LC}_{50}$ of greater than $1000 \mu \mathrm{g} / \mathrm{mL}$ towards Artemia nauplii have been defined as being nontoxic. ${ }^{40}$

\section{DISCUSSION}

Many Terminalia spp. have a history of therapeutic usage to treat microbial infections and numerous recent investigations have reported on their antibacterial properties. T. arjuna leaf and branch extracts have antibacterial activity against a wide panel of microbes. ${ }^{19,20}$ T. chebula also has a tradition of use in Ayurveda for the treatment of numerous diseases and conditions. ${ }^{21} T$. chebula has also been reported to display potent antibacterial activity against a microbial panel. ${ }^{19}$ Similarly, T. alata, T.bellirica and T.catappa havealso been reported to have broad spectrum antibacterial activity. ${ }^{20}$ Interestingly, whilst $B$. anthracis was not tested in any of the previous studies, several reports indicate strong growth

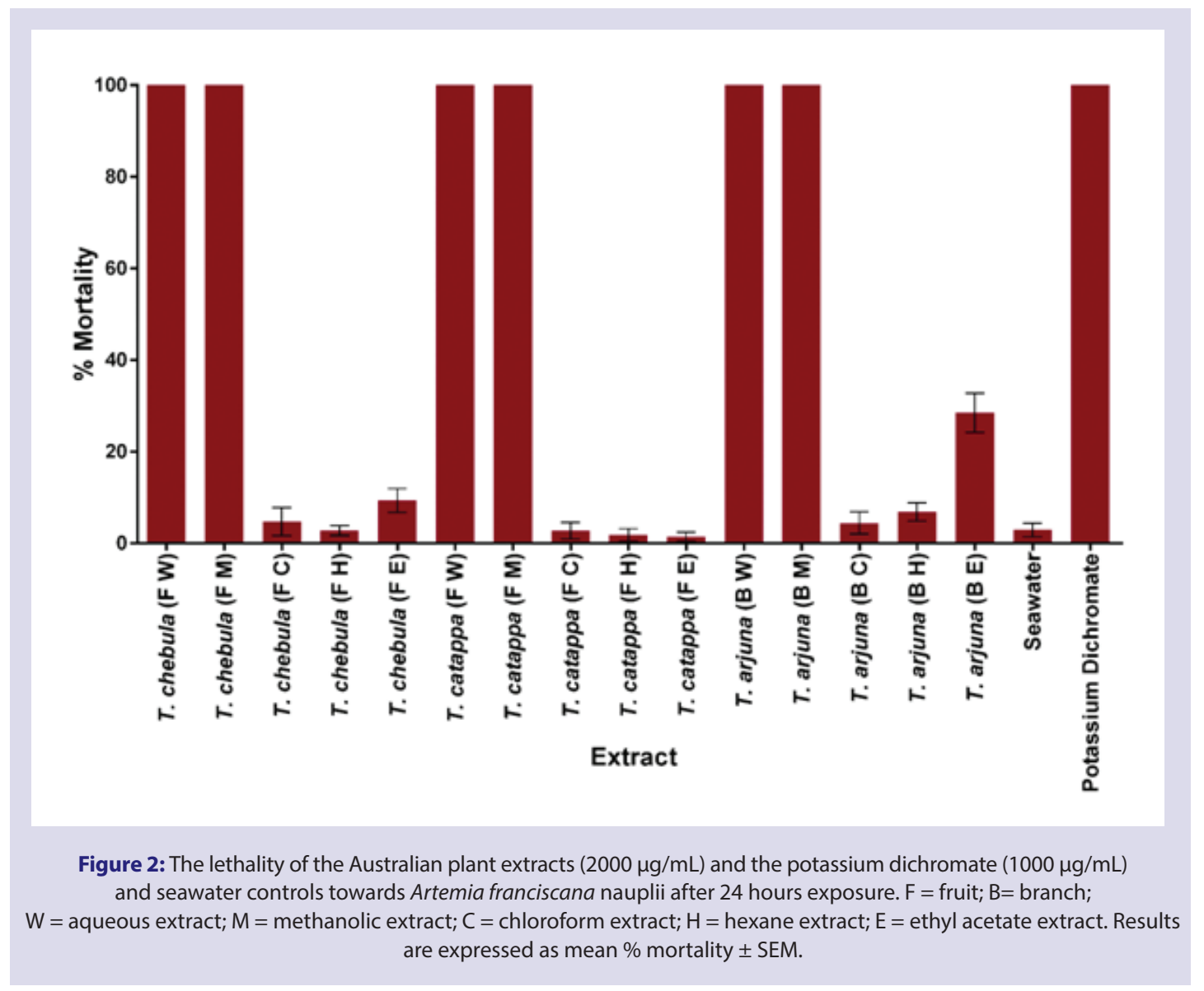


Wright et al.: Indian Terminalia inhibit Bacillus anthracis growth

inhibition of the related bacterial species Bacillus subtilis. T. catappa was a particularly potent growthinhibitor, with an MICof $5 \mu \mathrm{g} / \mathrm{mL}$ reported. ${ }^{41}$ A different study reported growth inhibition of 2 Bacillus spp. including B. subtilis at doses as low as $100 \mu \mathrm{g} / \mathrm{mL} .{ }^{42}$ Similarly, inhibition of B. subtilis growth was reported for T. arjuna at $1000 \mu \mathrm{g} / \mathrm{mL} .{ }^{43}$ However, that study did not report MIC values, making it difficult to compare efficacy between the extracts. B. subtilis is closely related to B. anthracis with approximately 95\% $16 \mathrm{~S}$ rRNA sequence homology. ${ }^{44}$ Indeed, under current taxonomic standards, bacteria with $>97 \% 16$ S rRNA sequence homology are generally classified as a single species. It is therefore perhaps not surprising that the Indian Terminalia spp. extracts screened in our study displayed growth inhibitory activity towards B. anthracis.

Whilst an examination of the phytochemistry of the Terminalia spp. examined in our study was beyond the scope of our study, a commonality of this genus is their relatively high levels of a number of tannin components including exifone (4-galloylpyrogallol), ellagic acid dehydrate, trimethylellagic acid, chebulic acid, corilagen, castalagin and chebulagic acid. ${ }^{11,13-15}$ Gallotannin shave been reported to inhibit the growth of a broad spectrum of bacterial species ${ }^{45}$ through a variety of mechanisms including binding cell surface molecules including lipotoichoic acid and proline-rich cell surface proteins $s^{46,47}$ and by inhibiting glucosyltransferase enzymes. ${ }^{48}$ Elligitannins are also highly potent inhibitors of bacterial growth, with MIC values as low as $62.5 \mu \mathrm{g} / \mathrm{ml}^{45}$ Ellagitannins have also been reported to function via several antibiotic mechanisms including interaction with cytoplasmic oxidoreductases and by disrupting bacterial cell walls. ${ }^{45,47}$ It is likely that other phytochemical classes also contribute to the growth inhibitory properties of these extracts. Our qualitative phytochemical screening studies indicate that polyphenolics, flavonoids, saponins, and terpenes were present in the Terminalia spp. extracts. Terpenoids have been previously reported to have potent broad spectrum antibacterial activity ${ }^{49}$ and therefore may contribute to the inhibitory activity against $B$. anthracis. Many studies have also reported potent antibacterial activities for a wide variety of flavonoids. ${ }^{50}$ Further phytochemical evaluation studies and bioactivity driven isolation of active components is required to further evaluate the mechanism of B. anthracis growth inhibition.

The findings reported here demonstrate that all of the Indian Terminalia extracts tested in our study were nontoxic towards Artemia franciscananauplii, with $\mathrm{LC}_{50}$ values substantially $>1000 \mu \mathrm{g} / \mathrm{mL}$. Extracts with $\mathrm{LC}_{50}$ values $>1000 \mu \mathrm{g} / \mathrm{mL}$ towards Artemia nauplii are defined as being nontoxic. ${ }^{40}$ Whilst our preliminary toxicity studies indicate that these extracts may be safe for use as $B$. anthracis growth inhibitors, studies using human cell lines are required to further evaluate the safety of these extracts. Furthermore, whilst the results of our study are promising, it must be noted that the growth inhibitory studies screened against vegetative cells. As Bacillus spp. are spore formers, further studies are required to determine whether extracts with $B$. anthracis growth inhibitory activity also affect bacterial growth from the spores.

\section{CONCLUSION}

The results of this study demonstrate the potential of various Indian Terminalia spp. in the growth inhibition of $B$. anthracis. Further investigations aimed at the purification of the bioactive components are needed to assess the mechanisms of action of these agents.

\section{ACKNOWLEDGEMENTS}

We are most grateful to Dr Paran Rayan for supplying the plant specimens used in this study. Financial support for this work was provided by the Environmental Futures Research Institute and the School of
Natural Sciences, Griffith University, Australia.

\section{CONFLICTS OF INTEREST}

The authors report no conflicts of interest.

\section{ABBREVIATION USED}

DMSO: Dimethyl sulfoxide; $\mathbf{L C}_{50}$ : The concentration required to achieve 50\% mortality; MIC: Minimum inhibitory concentration; PYE: Peptone yeast extract.

\section{REFERENCES}

1. Firoved AM, Miller GF, Moayeri M, et al. Bacillus anthracis edematoxin causes extensive tissue lesions and rapid lethality in mice. The American Journal of $\mathrm{Pa}-$ thology. 2005;67(5):1309-20. http://dx.doi.org/10.1016/S0002-9440(10)61218-7

2. Pilo P, Frey J. Bacillus anthracis: Molecular taxonomy, population genetics, phylogeny andpatho-evolution. Information, Genetics and Evolution. 2011;11: 1218-124. http://dx.doi.org/10.1016/j.meegid.2011.05.013; PMid:21640849

3. Wright $\mathrm{MH}$, Greene $\mathrm{AC}$, Cock IE. Inhibition of Bacillus anthracis growth by Australian native plants used traditionally as Antibacterial medicines. Pharmacognosy Journal. 2015;7(6):389-96. DOI : 10.5530/pj.2015.6.13 http://dx.doi.org/ 10.5530/pj.2015.6.13

4. Bezymennyi M, Bagamian KH, Barro A, et al. Spatio-temporal patterns of livestock anthrax in Ukraine during thepast century. Applied Geography. 2014;54:129-38. http://dx.doi.org/10.1016/j.apgeog.2014.07.016

5. Fridlander AM. Clinical aspects, diagnosis and treatment of anthrax. Journal of Applied Microbiology. 1999;87:303. http://dx.doi.org/10.1046/j.1365-2672. 1999.00896.x

6. Kolbe A, Yuen MG, Doyle BK. A case of human cutaneous anthrax. The Medical Journal of Australia. 2006;185(5):281-2. PMid:16948627

7. Sirisanthana T, Brown AE. Anthrax of the gastrointestinal tract. Emerging Infectious Diseases. 2002;8(7):649-51. http://dx.doi.org/10.3201/eid0807.020062; PMid:12095428 PMCid:PMC2730335

8. Barr J, Boyer AE, Quinn CP. Anthrax: modern exposure science combats a deadly, ancient disease. Journal of Exposure Science and Environmental Epidemiology. 2010;20:573-4. http://dx.doi.org/10.1038/jes.2010.49; PMid:20959831

9. Bell DM, Kozarsky PE, Stephens DS. Clinical issues in the prophylaxis, diagnosis, and treatment of anthrax. Emerging Infectious Diseases. 2002;8(2). http:// dx.doi.org/10.3201/eid0802.01-0521

10. Schneemann A, Manchester M. Anti-toxin antibodies in prophylaxis and treatment of inhalation anthrax. Future Microbiology. 2009;4(1):35-43. http://dx.doi. org/10.2217/17460913.4.1.35 ; PMid:19207098 PMCid:PMC2710805

11. Cock IE. The medicinal properties and phytochemistry of plants of the genus Terminalia (Combretaceae). Inflammopharmacology. 2015;23(5):203-29. DOI 10.1007/s10787-015-0246-z http://dx.doi.org/10.1007/s10787-015-0246-z

12. Cock IE, Mohanty S. Evaluation of the antibacterial activity and toxicity of Terminalia ferdinandiana fruit extracts. Pharmacognosy Journal. 2011;3(20):72 9. DOI: 10.5530/pj.2011.20.14 http://dx.doi.org/10.5530/pj.2011.20.14

13. Sirdaarta J, Matthews B, Cock IE. Kakadu plum fruit extracts inhibit growth of the bacterial triggers of rheumatoid arthritis: Identification of stilbene and tannin components. Journal of Functional Foods. 2015;17:610-20. DOI: 10.1016/j. jff.2015.06.019 http://dx.doi.org/10.1016/j.jff.2015.06.019

14. Sirdaarta J, Matthews B, White A, et al. GC-MS and LC-MS analysis of Kakadu plum fruit extracts displaying inhibitory activity against microbial triggers of multiple sclerosis. Pharmacognosy Communications. 2015;5(2):100-15. DOI: 10.5530/pc.2015.2.2 http://dx.doi.org/10.5530/pc.2015.2.2

15. Courtney R, Sirdaarta J, Matthews B, et al. Tannin components and inhibitory activity of Kakadu plum leaf extracts against microbial triggers of autoimmune inflammatory diseases. Pharmacognosy Journal. 2015;7(1):18-31. DOI: 10.5530/pj.2015.7.2 http://dx.doi.org/10.5530/pj.2015.7.2

16. Mbwambo ZH, Erasto $P$, Nondo RO, et al. Antibacterial and cytotoxic activities of Terminalia stenostachya and Terminalia spinosa. Tanzania Journal of Health Research. 2011;13 (2):1-8. http://dx.doi.org/10.4314/thrb.v13i2.64759

17. Cock IE, van Vuuren SF. Anti-Proteus activity of some South African medicinal plants: Their potential for the prevention of rheumatoid arthritis. InflammoPharmacology. 2014;22:23-36. DOI 10.1007/s10787-013-0179-3 http://dx.doi. org/10.1007/s10787-013-0179-3

18. Cock IE, van Vuuren SF. A comparison of the antimicrobial activity and toxicity of six Combretum and two Terminalia species from Southern Africa. Pharmacognosy Magazine. 2015;11(4):208-18. DOI 10.4103/0973-1296.149740 http:// dx.doi.org/10.4103/0973-1296.149740

19. Aneja KR, Sharma C, Joshi R. Antimicrobial activity of Terminalia arjuna Wight \&Arn: An ethnomedicinal plant against pathogens causing ear infection. Brazilian Journal of Otorhinolaryngology. 2012;78(1):68-74. http://dx.doi.org/10.1590/ S1808-86942012000100011 PMid:22392241 
20. Shinde SL, Junne SB, Wadje SS, Baig MMV. The diversity of antibacterial compounds of Terminalia species (Combretaceae). Pakistan Journal of Biological Sciences. 2009;12(22):1483-86. http://dx.doi.org/10.3923/pjbs.2009. 1483.1486 PMid:20180323

21. Chopra RN, Nayar SL, Chopra IC. Glossary of Indian medicinal plants. New Delhi, CSIR, 1956.

22. Adebayo EA, Iswhola OR. Phytochemical and antimicrobial screening of crude extracts from the root, stem bark, and leaves of Terminalia glaucescens. African Journal of Pharmacy and Pharmacology. 2009;3(5):217-21.

23. Ratha KK, Joshi GC. Haritaki (Chebulicmyrobalan) and its varieties. Ayu 2013; 34(3):331-4. http://dx.doi.org/10.4103/0974-8520.123139 PMid:24501534 PMCid:PMC3902605

24. Chanda S, Rakholiya K, Nair R. Antimicrobial activity of Terminalia catappa L. leaf extracts against some clinically important pathogenicmicrobial strains. Chinese Medicine. 2011;2:171-7. http://dx.doi.org/10.4236/cm.2011.24027

25. Nagappa AN, Thakurdesai PA, Venkat Rao N, et al. Antidiabetic activity of Terminalia catappaLinn fruits. Journal of Ethnopharmacology. 2003;88(1):45-50. http://dx.doi.org/10.1016/S0378-8741(03)00208-3

26. Dwivedi S. Terminalia arjuna Wight \& Arn. A useful drug for cardiovascular disorders. Journal of Ethnopharmacology. 2007;114(2):114-29. http://dx.doi. org/10.1016/j.jep.2007.08.003 PMid:17875376

27. Ram A, Lauria P, Gupta R, et al. Hypocholesterolaemic effects of Terminalia arjuna tree branch. Journal of Ethnopharmacology. 1997;55(3):165-9. http:// dx.doi.org/10.1016/S0378-8741(96)01493-6

28. Arkhipov A, Sirdaarta J, Rayan $\mathrm{P}$, et al. An examination of the antibacterial, antifungal, anti-Giardial and anticancer properties of Kigelia africana fruit extracts. Pharmacognosy Communications. 2014;4(3):62-76. DOI: 10.5530/ pc.2014.3.7 http://dx.doi.org/10.5530/pc.2014.3.7

29. Hart C, Ilanko P, Sirdaarta J, et al. Tasmannia stipitata as a functional food/natural preservative: Antimicrobial activity and toxicity. Pharmacognosy Communications. 2014;4(4):33-47. DOI: 10.5530/pc.2014.4.4

30. Winnett $\mathrm{V}$, Boyer $\mathrm{H}$, Sirdaarta J, et al. The potential of Tasmannia lanceolata as a natural preservative and medicinal agent: Antimicrobial activity and toxicity. Pharmacognosy Communications. 2014;4(1):42-52. DOI: 10.5530/pc.2014.1.7 http://dx.doi.org/10.5530/pc.2014.1.7

31. Wright MH, Matthews $B$, Greene AC, et al. Growth inhibition of the zoonotic bacteria Bacillus anthracis by high antioxidant Australian plants: Newleads for the prevention and treatment of anthrax. Pharmacognosy Communications. 2015; 5(3):173-89. DOI: 10.5530/pc.2015.3.3 http://dx.doi.org/10.5530/pc.2015.3.3

32. Cock IE, van Vuuren SF. A comparison of the antimicrobial activity and toxicity of six Combretum and two Terminalia species from Southern Africa. Pharmacognosy Magazine 2015; 11(4): 208-218. DOI 10.4103/0973-1296.149740 http:// dx.doi.org/10.4103/0973-1296.149740

33. Kalt FR, Cock IE. Gas chromatography-mass spectroscopy analysis of bioactive Petalostigma extracts: Toxicity, antibacterial and antiviral activities. Pharmacognosy Magazine. 2014;10(37 Supp):S37-S49. DOI: 10.4103/0973-1296.127338 http://dx.doi.org/10.4103/0973-1296.127338

34. Sautron C, Cock IE. Antimicrobial activity and toxicity of Syzygium australe and Syzygium leuhmannii fruit extracts. Pharmacognosy Communications. 2014; 4(1):53-60. DOI: 10.5530/pc.2014.1.8 http://dx.doi.org/10.5530/pc.2014.1.8

35. Vesoul J, Cock IE. The potential of Bunya nut extracts as antibacterial functional foods. Pharmacognosy Communications. 2012;2(1):72-9. DOI: 10.5530/ pc.2012.1.13 http://dx.doi.org/10.5530/pc.2012.1.13

36. Boyer $\mathrm{H}$, Cock IE. Evaluation of the potential of Macademia integriflora extracts as antibacterial food agents. Pharmacognosy Communications. 2013;3(3):53-62 DOI: $10.5530 / p c .2013 .3 .10$

37. Kalt FR, Cock IE. The medicinal potential of Australian native plants from Toohey Forest, Australia. The South Pacific Journal of Natural Science. 2011;28:41-7. DOI: 10.1071/SP10003 http://dx.doi.org/10.1071/SP10003

38. Ruebhart DR, Wikramasinghe WA, Cock IE. Protective efficacy of the antioxidants vitamin $\mathrm{E}$ and Trolox against Microcystis aeruginosa and microcystin-LR in Artemia franciscana nauplii. Journal of Toxicology and Environmental Health Part A. 2009:72(24):1567-75. DOI: 10.1080/15287390903232459 http://dx.doi. org/10.1080/15287390903232459

39. Cock IE, van Vuuren SF. South African food and medicinal plant extracts as potential antimicrobial food agents. Journal of Food Science and Technology. 2015; DOI 10.1007/s13197-015-1806-3

40. Cock IE, Ruebhart DR. Comparison of the brine shrimp nauplii bioassay and the ToxScreen-II test for the detection of toxicity associated with Aloe vera (Aloe barbadensis Miller) leaf extract. Pharmacognosy Research. 2009;1(2):98-101.

41. Babayi H, Kolo I, Okogun J, et al. The antimicrobial activities of methanolic extracts of Eucalyptus camaldulensis and Terminalia catappa against some pathogenic microorganisms. Biokemistri. 2004;16(2):106-11.

42. Hogade MG, Jalalpure S, Kuthar S. Antibacterial activity of fruit extract of Terminalia chebula Retz. against some Gram positive and Gram negative bacteria. International Journal of Pharmacy and Pharmaceutical Science Research. 2011;1:26-9.

43. Jahan N, Ali S, Bhatti IA. (2011). Antimicrobial potential of gemmo-modified extracts of Terminalia arjuna and Euphorbia tirucalli. International Journal of Agriculture and Biology. 2011;13(6):1001-05.

44. Maughan H, Van der Auwera G. Bacillus taxonomy in the genomic era finds phenotypes to be essential though often misleading. Infection, Genetics and Evolution. 2011;11:789-97. http://dx.doi.org/10.1016/j.meegid.2011.02.001 PMid:21334463

45. Buzzini P, Arapitsas P, Goretti M, et al. Antimicrobial activity of hydrolysable tannins. Mini-Reviews in Medicinal Chemistry. 2008;8:1179-87. http://dx.doi. org/10.2174/138955708786140990 PMid:18855732

46. Wolinsky LE, Sote EO. Isolation of natural plaque-inhibiting substances from 'Nigerian chewing sticks'. Caries Research. 1984;18:216-25. http://dx.doi. org/10.1159/000260768

47. Hogg SD, Embery G. Blood-group-reactive glycoprotein from human saliva interacts with lipoteichoic acid on the surface of Streptococcus sanguis cells. Archives in Oral Biology. 1982;27:261-8. http://dx.doi.org/10.1016/00039969(82)90060-7

48. Wu-Yuan CD, Chen CY, Wu RT. Gallotannins inhibit growth, water-soluble glucan synthesis, and aggregation of Streptococci mutans. Journal of Dental Research. 1988;67:51-5. http://dx.doi.org/10.1177/00220345880670011001 PMid:11039045

49. Cock IE. The phytochemistry and chemotherapeutic potential of Tasmania lanceolata (Tasmanian pepper): A review. Pharmacognosy Communications 2013:3(4):1-13.DOI: 10.5530/pc.2013.4.3

50. Narayana KR, Reddy MS, Chaluvadi MR, et al. Bioflavonoids classification, pharmacological, biochemical effects and therapeutic potential. Indian Journal of Pharmacology. 2001;33(1):2-16.

\section{PICTORIAL ABSTRACT}

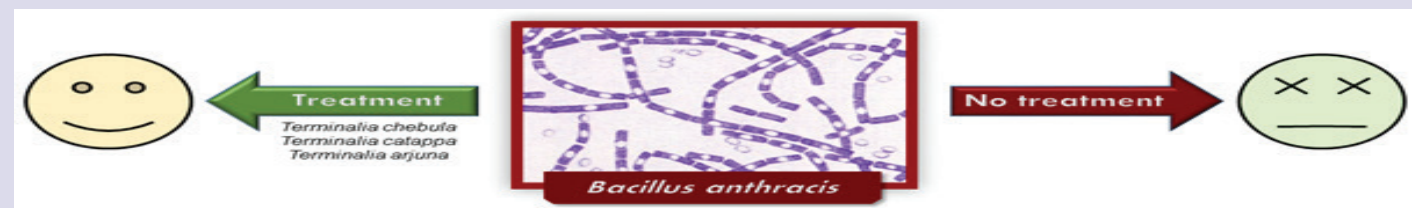

\section{SUMMARY}

- Extracts of 3 Indian Terminalia spp.inhibited B. anthracis growth

- T. chebula fruit methanolic extract was particularly potent, with an MIC of $166 \mu \mathrm{g} / \mathrm{mL}$.

- Aqueous T. chebula and methanolic T. catappa and T. arjuna extracts also were good growth inhibitors (MIC's $<2500 \mu \mathrm{g} / \mathrm{mL}$ )

- Hexane and ethyl acetate extracts were generally devoid of inhibitory activity.

- All the extracts were non-toxic in the Artemia nauplii assay. 


\section{ABOUT AUTHORS}

Dr Mitchell Henry Wright: Received his PhD in 2014, for his work investigating the manganese reduction and oxidation characteristics of environmental bacteria. He is currently a postdoctoral researcher at Griffith University, Australia, where he is working on several projects both in the areas of geomicrobiology and pharmocognosy. His present research interests are the use of biogenic manganese oxides in the bioremediation of metal-contaminated sites as well as the use of Australian native plants in the treatment and prevention of various pathogenic bacteria.

Reece Courtney: Is a current post graduate student in the School of Natural Sciences Griffith University, Australia under the supervision of Dr lan Cock. His research interests include medical microbiology, pharmacognosy and medicinal plants. He has a particular interest in the medicinal properties of the genus Terminalia, which is the subject of his research project.

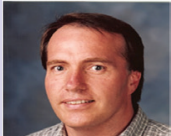

Dr Anthony Greene: Is a senior lecturer and researcher at Griffith University, Brisbane Australia. He obtained his PhD in Microbiology from the University of New South Wales and focuses on extreme environments, bioremediation and Geomicrobiology. His specific interests include the microbial ecology of thermophilic, saline and alkaliphilic environments and the mechanisms and industrial potential of extremophilic bacteria contained therein.

Dr lan Cock : Leads a research team in the Environmental Futures Research Institute and the School of Natural Sciences at Griffith University, Australia. His research involves bioactivity and phytochemical studies into a variety of plant species of both Australian and international origin including Aloe vera, South Asian and South American tropical fruits, as well as Australia plants including Scaevolaspinescens, Pittosporum phylliraeoides, Terminalia ferdinandiana (Kakadu plum), Australian Acacias, Syzygiums, Petalostigmas and Xanthorrhoea johnsonii (grass trees). This range of projects has resulted in nearly 200 scientific publications in a variety of peer reviewed journals. 